\title{
Effects of long-term differences in fertiliser history on hill country: seasonal pasture production, legume growth and soil phosphorus status
}

\author{
C.G. ROACH', E.K.K. NEMAIA ${ }^{2}$, S.F. LEDGARD ${ }^{2}$, G.J. BRIER ${ }^{2}$ and C.D.A. McLAY ${ }^{3}$ \\ ${ }^{1}$ AgResearch Te Kuiti Research Area, PO Box 277, Te Kuiti \\ ${ }^{2}$ AgResearch Ruakura, Private Bag 3123, Hamilton \\ ${ }^{3}$ University of Waikato, Private Bag 310.5, Hamilton
}

\begin{abstract}
The effects of 10 years of nil or maintenance phosphorus (P) fertiliser $(250 \mathrm{~kg} / \mathrm{ha} / \mathrm{yr}$ superphosphate) on pasture production and composition, and on soil $\mathrm{P}$ status, were measured in a farmlet trial on hill country near Te Kuiti. Withholding P resulted in $29-35 \%$ less annual pasture production and 54-72\% less legume (predominantly white clover) production. There was little difference in seasonality of production between the two farmlets. The loss in production in the nil $\mathrm{P}$ farmlet was predictable based on the decline in soil Olsen $\mathrm{P}$ test to $6-8 \mathrm{ppm}$ and the results from past mowing trials. Additional soil measurements revealed that soil organic $\mathrm{P}$ levels were increasing at the site and this will have contributed to the decline in plantavailable $P$ in soil. Re-application of $P$ at $23 \mathrm{~kg} / \mathrm{ha}$ markedly increased legume growth (by $180-330 \%$ ) in the nil $\mathrm{P}$ farmlet, which was proportionally twice as high on steep slopes as on easy slopes. This response in legume production was most evident in summer at a time when improved feed quality is valuable for finishing lambs. Indeed, legume growth in the $\mathrm{P}$ re-application plots exceeded that in the maintenance $\mathrm{P}$ farmlet by $23-28 \%$. This reflected reduced plant-available soil $\mathrm{N}$ status due to less inputs from $\mathrm{N}_{2}$ fixation in the previous 10 years, and thereby increased the competitive advantage of legumes over grasses where $\mathrm{P}$ deficiency was diminished by fertiliser re-application.
\end{abstract}

Keywords: fertiliser history, hill country, legume production, pasture production, phosphorus, seasonality, soil phosphorus

\section{Introduction}

Phosphorus (P) is a major limiting nutrient to pasture production on North Island hill country, as identified in a summary of soil test levels on sheep and beef farms with $7 \mathrm{I} \%$ below soil Olsen $\mathrm{P}$ of $15 \mathrm{ppm}$ (Ledgard et al. 1991). Field trials on hill country showed that withholding $\mathrm{P}$ fertiliser led to a steady decline in annual pasture and sheep production by up to one third over
4-7 years (Lambert et al. 1990; O'Connor et al. 1990). In addition, these trials showed deterioration in pasture species composition with increased weeds and a decline in white clover and/or ryegrass content

The aim of the present study was to determine the effect of long-term (10+ years) differences in superphosphate application on seasonal pasture production, legume growth and soil $\mathrm{P}$ status.

\section{Methods}

Trial site

A long-term farmlet grazing trial at the AgResearch Te Kuiti Research Area was established in 1983 and includes treatments of 0 and $250 \mathrm{~kg} / \mathrm{ha} / \mathrm{yr}$ superphosphate (subsequently designated as $\mathrm{OP}$ and $+\mathrm{P}$ respectively). The soil is predominantly sedimentary (Brown Soil, Hewitt 1992), with a small variable component of volcanic ash in the topsoil. The stocking rate since 1988 has been 11 and 15 ewes/ha in the OP and $+\mathrm{P}$ farmlets respectively (previously it was 14 ewes/ha in both farmlets). Sheep management was described by O'Connor et al. (1 990).

\section{Measurements}

In each farmlet, 4 plots $(2.0 \mathrm{~m} \times \mathrm{I} .0 \mathrm{~m})$ were located on easy $\left(10-20^{\circ}\right)$ or steep (25-35”) slopes, in 4 paddocks with either north or south aspects. Within the OP farmlet, all plots were paired and one pair received a P re-application treatment of $250 \mathrm{~kg} / \mathrm{ha} / \mathrm{yr}$ superphosphate.

During 1992-1 994 (years IO and 11 of the farmlet trial), detailed measurements were made of total pasture production and species composition (by herbage separation at each cut) in the plots. Pasture production was measured monthly (or 6-weekly in winter) using a trim/cut technique with an exclosure cage being rotated within each plot after each cut.

All plots received annual applications of sulphate of potash (63 kg K/ha and $25 \mathrm{~kg} \mathrm{~S} / \mathrm{ha})$ and a trace element mix (containing Mo, Cu, Na, B and $\mathrm{Zn}$ ) to ensure that any differences measured were due to $\mathrm{P}$ effects. Previous pasture measurements revealed that withholding superphosphate led to $\mathrm{P}$ deficiency, but to nil or marginal $\mathrm{S}$ deficiency. 
Soil samples $(0-7.5 \mathrm{~cm}$ depth) were collected from all plots at the start of the study and analysed for Olsen $P$. At the same time, soil samples $(0-30 \mathrm{~cm})$ were collected from flat/camp (O-IO'), easy (1 I-25”) and steep $\left(>25^{\circ}\right)$ slopes in each of 6 paddocks in the OP and $+\mathrm{P}$ farmlets, and in an adjacent virgin bush area. These samples were sectioned into 0-7.5, 7.5-15 and 15-30 $\mathrm{cm}$ depths, air-dried, ground and sieved $(<150 \mathrm{pm})$. They were then analysed for inorganic $\mathrm{P}$ after extraction with $0.5 \mathrm{M} \mathrm{H}_{2} \mathrm{SO}_{4}$, and for total $\mathrm{P}$ after ignition $\left(550^{\circ} \mathrm{C}\right)$ and extraction with $0.5 \mathrm{M} \mathrm{H}_{2} \mathrm{SO}_{4}$ (Perrott 1992). Organic $\mathrm{P}$ was estimated by difference between total $\mathrm{P}$ and inorganic $\mathrm{P}$

Trial results were analysed as a split, split plot design using GENSTAT.

\section{Results and discussion}

\section{Total pasture production}

Annual pasture production in the regularly fertilised (+P) farmlet was 41 and $53 \%$ higher than in the farmlet which had received no fertiliser during the previous 10 years (OP), in years 1 and 2 respectively (average for all strata, Table 1). This is slightly higher than the increase in stocking rate in $+\mathrm{P}$ over OP of $36 \%$ (15 vs 1 I ewes/ ha) but less than the increase in lamb weaning weight/ ha of 119 and $77 \%$ in years 1 and 2 respectively. Thus, $P$ deticiencywas having a major effect on pasture and animal productivity.

Table 1 Effect of $\mathrm{P}$ fertiliset history on total pasture and legume production. Results represent the mean of all aspects and slopes.

\begin{tabular}{cccccc}
\hline & OP & $\begin{array}{c}\mathrm{P} \\
\text { reapplication }\end{array}$ & $+\mathrm{P}$ & $\mathrm{SED}^{1}$ & $\mathrm{SED}^{2}$ \\
\hline $\begin{array}{c}\text { Total production } \\
\text { (kg DM/ha/yr) }\end{array}$ & & & & & \\
Year 1 & 4614 & 6112 & 6764 & 838 & 284 \\
Year 2 & 5320 & 6240 & $\mathbf{8 1 2 9}$ & $\mathbf{8 9 0}$ & 306 \\
$\begin{array}{c}\text { Legume production } \\
\text { (kg DM/ha/yr) }\end{array}$ & & & & & \\
Year 1 & 491 & 1361 & 1060 & 135 & 150 \\
Year 2 & 343 & 1488 & 1207 & 134 & 112 \\
\hline
\end{tabular}

1 For comparison between $O P$ and $+P$ treatments

2 For comparison between OP and $P$ reapplication treatments

Re-application of $\mathrm{P}$ fertiliser on the OP farmlet increased annual pasture production by 27 and $17 \%$ in years 1 and 2 respectively. Thus, even a relatively low rate of application, following 10 years without added $\mathrm{P}$, increased $(\mathrm{P}<0.01)$ production by $1 / 3$ to $2 / 3$ of the increase in the regularly fertilised farmlet (Table 1). In a mowing trial on a nearby site, Ledgard \& Brier (1993) also measured a significant response to $20 \mathrm{~kg} \mathrm{P} / \mathrm{ha}$ on a low $\mathrm{P}$ status site, and suggested that two capital dressings of $80 \mathrm{~kg} \mathrm{P} / \mathrm{ha} / \mathrm{yr}$ increased production to near that from regular fertiliser application.

Seasonality of total pasture production was generally similar for all $\mathrm{P}$ fertiliser histories, with the percentage response to $+\mathrm{P}$ being about $50 \%$ in all seasons when averaged over both years (Figure 1). Similarly, P deficiency had no effect on seasonality of production in Northland (M.B. O'Connor, unpublished) and on Manawatu hill country (Lambert et al. 1990).

Figure 1 Effect of $\mathrm{P}$ fettiliser history on seasonal pasture production. Bars represent SEDs.

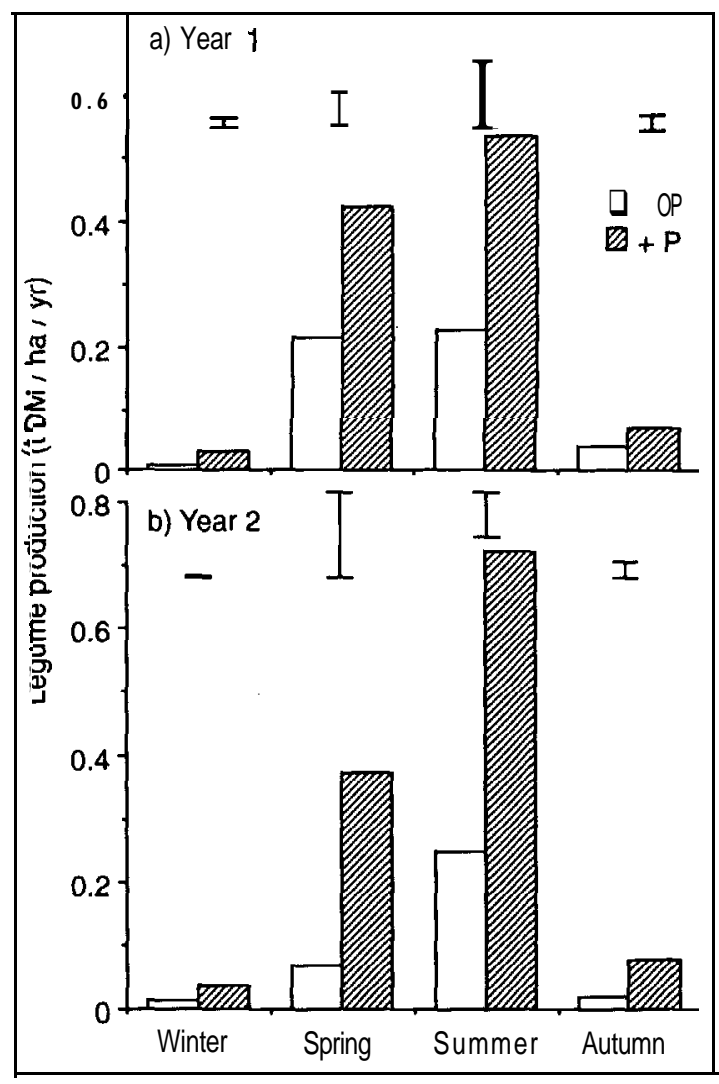

Aspect had no significant effect on total pasture production. In contrast, there was a marked effect of land slope on production, with average annual yields of 8450 and $4060 \mathrm{~kg} \mathrm{DM} / \mathrm{ha} / \mathrm{yr}$ on 10-20" and 25-35" slopes respectively. There was no significant effect of aspect or slope on the percentage increase in production in $+\mathrm{P}$ relative to $\mathrm{OP}$ farmlets. However, the greater potential productivity on easy slopes meant that the amount of extra pasture grown due to regular $\mathrm{P}$ 
application on easy slopes was approximately twice that from steep slopes.

\section{Legume production}

Withholding $\mathrm{P}$ for 10 years led to a much larger decline in legume production (by 54-72\%) than in total pasture production (by 29-35\%) (Table 1), as also measured in summer-dry hill country by Mackay et al. (I 990). The legume was predominantly white clover, although Lotus spp. was present in the OP farmlet, particularly on southfacing slopes.

Re-application of $\mathrm{P}$ in the $\mathrm{OP}$ farmlet led to a marked response in legume growth (by 180-330\%). Indeed the increase in legume production corresponded closely with the increase in total pasture production, as observed in other studies (Edmeades et al. 1990; Ledgard \& Brier 1993). Thus, legume was the most responsive component in the pasture and was capable of a rapid and large response to $\mathrm{P}$ fertiliser even where $\mathrm{P}$ had been withheld for 10 years.

An interesting result was that legume production in the $\mathrm{P}$ re-application plots exceeded that in the $+\mathrm{P}$ plots by $23-28 \%$. This reflected the decline in plant-available nitrogen $(\mathrm{N})$ status in OP soil during the previous 10 years due to reduced inputs via $\mathrm{N}_{2}$ fixation by legumes. When $\mathrm{P}$ deficiency was diminished by re-application of $\mathbf{p}$ fertiliser, the legume was at a competitive advantage relative to grasses because of low plant-available soil $\mathrm{N}$. This was confirmed by associated measurements (Ledgard $e t$ al. unpublished) using the stable isotope ${ }^{15} \mathrm{~N}$ to determine the sources of $\mathrm{N}$ utilised by plants. These measurements showed that legumes derived 18\% of their $\mathrm{N}$ from soil (with the remainder from $\mathrm{N}_{2}$ fixation) in the $+\mathrm{P}$ farmlet whereas only $13 \%$ of legume $\mathrm{N}$ came from soil in the OP farmlet. Thus, the accumulation of $\mathrm{N}$ in soil in the $+\mathrm{P}$ farmlet over time has favoured an increase in $\mathrm{N}$ available for uptake by all plants, including legumes. This has resulted in an increase in N-responsive ryegrass and greater competition by grasses (Ledgard \& Steele 1992), thereby limiting legume production relative to that in the $\mathrm{P}$ re-application plots of the OP farmlet.

There were no consistent seasonal differences in legume production from $\mathrm{OP}$ relative to $+\mathrm{P}$ farmlets, with the increase to $+\mathrm{P}$ being about 120 and $250 \%$ in years 1 and 2 respectively (Figure 2). However, the response to re-application of $\mathrm{P}$ to plots in the OP farmlet was clearly most marked in summer (Figure 2). About $30 \%$ (or $94 \%$ in $\mathrm{P}$ re-application plots) of annual legume roduction occurred during spring and summer, The ncreased legume production and improved feed quality ver summer in the P-fertilised pasture would be eneficial for finishing lambs.

Aspect had no significant effect on legume roduction. In contrast, land slope affected legume
Figure 2 Effect of $\mathrm{P}$ fertiliser history and $\mathrm{P}$ re-application in the OP farmlet on seasonal legume production. Bars represent SEDs.

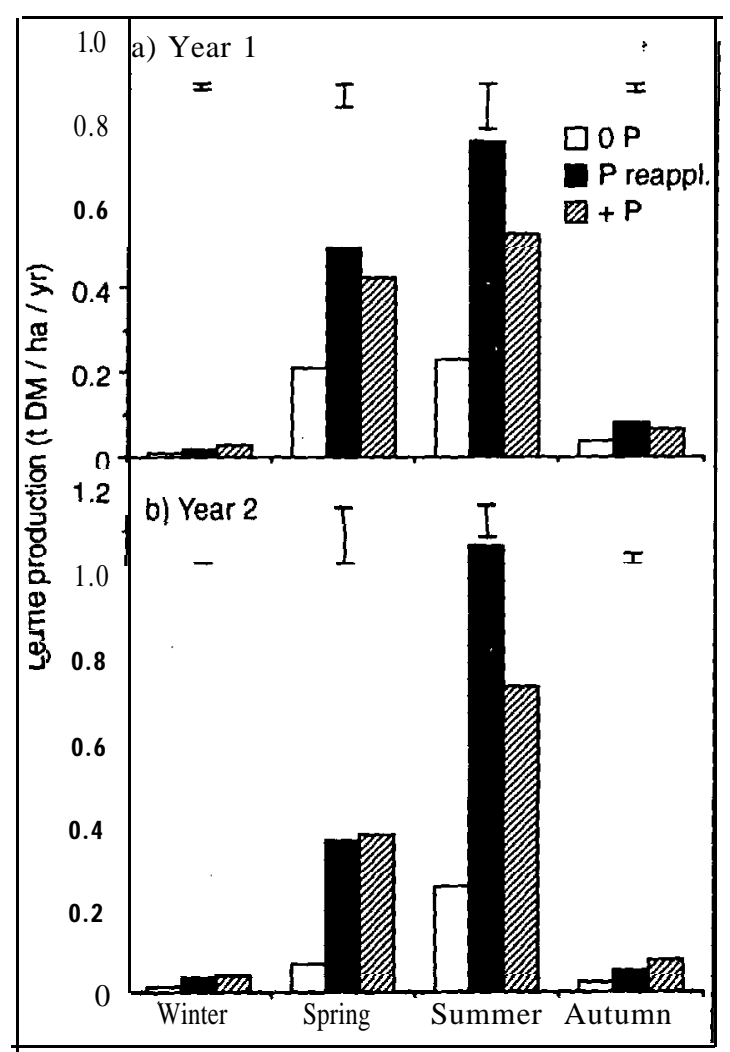

production by a similar magnitude to total pasture production, with average legume yields of 990 and 560 $\mathrm{kg} \mathrm{DM} / \mathrm{ha} / \mathrm{yr}$ on $10-20^{\circ}$ and $25-35$ " slopes respectively.

The percentage increase in legume growth in $+P$ farmlets compared with OP farmlets was similar on easy and steep slopes in year 1 but was twice as high on steep slopes as on easy slopes in year 2 (Figure 3). Similarly, $\mathrm{P}$ re-application in the OP farmlet resulted in a percentage response on steep slopes which was approximately twice that on easy slopes. Thus, there was relatively little difference in the amount of legume production on steep and easy slopes of the $\mathrm{P}$ reapplication treatment.

\section{Soil P status}

The decline in pasture production from withholding $\mathbf{P}$ for 10 years and the responsiveness to added $P$ in the OP fannlet were not unexpected based on the decline in soil Olsen P test. The mean Olsen P test levels at the start of the measurement period were 8.0 and 6.5 for easy and steep slopes in the OP farmlet, and 13.0 and 
Figure 3 Land slope effects on legume production as affected by $\mathbf{P}$ fertiliser history and by Preapplication in the $\mathrm{OP}$ farmlet. Bars represent SEDs.

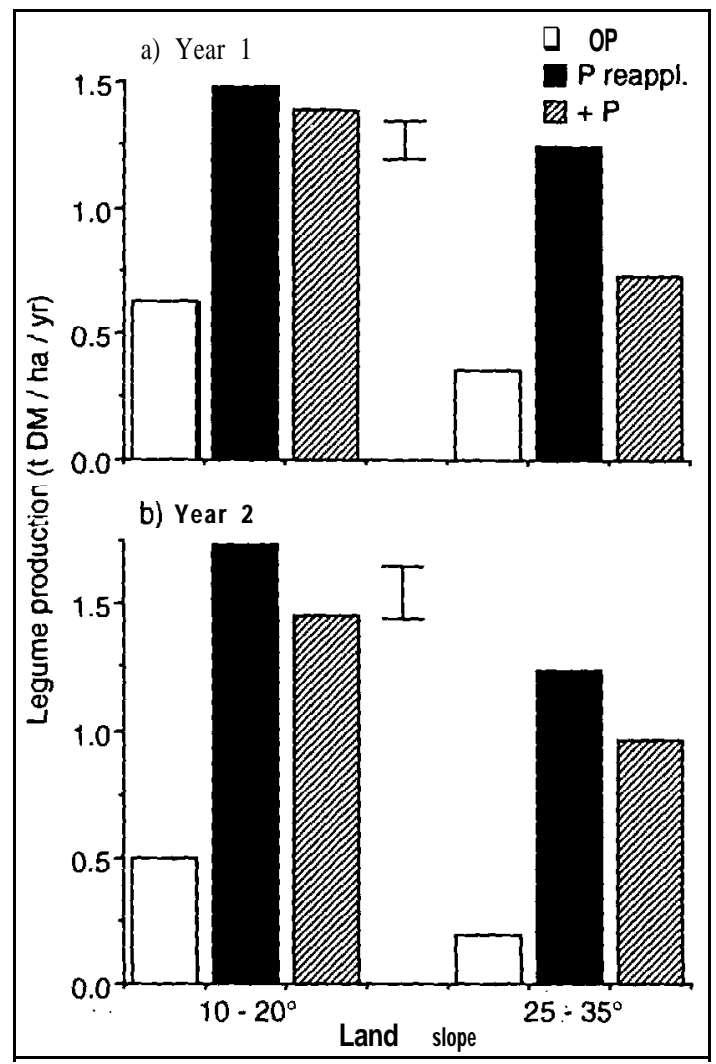

8.5 for easy and steep slopes in the $+\mathrm{P}$ farmlet respectively.

The average soil $\mathrm{P}$ retention tests were $80 \%$ on easy slopes and $75 \%$ on steep slopes indicating that there was some volcanic ash (typical P retention of $95 \%$ ) mixed in with the sedimentary parent material (a typical P retention for Brown Soils is about $40 \%$ ).

From the review of past mowing trials on these two soils, an Olsen $\mathrm{P}$ test of 6-S would coincide with approximately $65-75 \%$ of production relative to a non-P-limiting site (Morton et al. 1994). The corresponding value for an Olsen P test of 13 was about PO-95\%. This relative difference is similar to the production from $\mathrm{OP}$ relative to $+\mathrm{P}$ of $65-70 \%$ (Table I).

Differences in Olsen P between treatments were also reflected by similar relative differences in total inorganic $\mathrm{P}$ in soil (Figure 4). A detailed analysis of soils showed that $\mathrm{P}$ fertihser application since development from virgin bush has resulted in marked accumulation of $\mathrm{P}$ in soil, which was largely confined to the top $7.5 \mathrm{~cm}$ depth. Most P was in organic forms, which represented 93, 92 and $90 \%$ (SED $=0.5 \%$ ) of total soil $\mathrm{P}$ in the virgin bush, $\mathrm{OP}$ and $+\mathrm{P}$ farmlets respectively. Soil organic $\mathrm{P}$ is of limited plant availability as determined in another study at this site by Perrott (1992), which showed no net utilisation of organic P by plants. Indeed, Perrott (1992) showed that withholding $\mathrm{P}$ fertiliser resulted in a decline in inorganic $\mathrm{P}$ which was due in part to immobilisation into organic $\mathrm{P}$ forms. Results in Figure 4 show an increase in organic $\mathrm{P}$ with increasing $\mathrm{P}$ rate and suggest that organic $\mathrm{P}$ was still accumulating in these soils.

A budget of the fate of the additional $241 \mathrm{~kg} \mathrm{P} / \mathrm{ha}$ applied to the $+\mathrm{P}$ farmlet in excess of the $\mathrm{OP}$ farmlet (Table 2) indicates that there was increased loss in animal products of only $4 \mathrm{~kg} \mathrm{P} / \mathrm{ha}$, an additional $6 \mathrm{~kg}$ $\mathrm{P} / \mathrm{ha}$ remained in plants, and an extra $209 \mathrm{~kg} \mathrm{P} / \mathrm{ha}$ was

Table 2 Fate of $\mathbf{P}$ applied during the past 10 years on the $O P$ and $+P$ farmlets.

\begin{tabular}{lrrr}
\hline & OP & $+P$ & Increase in $+P$ \\
\hline$P$ inputs (kg P/ha) & & & \\
$\quad$ Fertiliser applied & 0 & 241 & 241 \\
$P$ outputs + soil/plant & & & \\
$P$ (kg P/ha) & & & \\
Total soil P & 1055 & 1264 & 209 \\
Removal in animal products & 57 & 61 & 4 \\
$P$ remaining in plants' & 12 & 16 & 6 \\
Total P accounted for & 1124 & 1343 & 219 \\
\hline P in pasture shoots and roots at time of soil sampling &
\end{tabular}

$P$ in pasture shoots and roots at time of soil sampling.

Figure 4 Inorganic (closed symbols) and total (open symbols) P concentration in soil as affected by $\mathbf{P}$ fertiliser histoiy and soil depth. Results are the means of 3 land slope categories. Bars regresent SEDs.

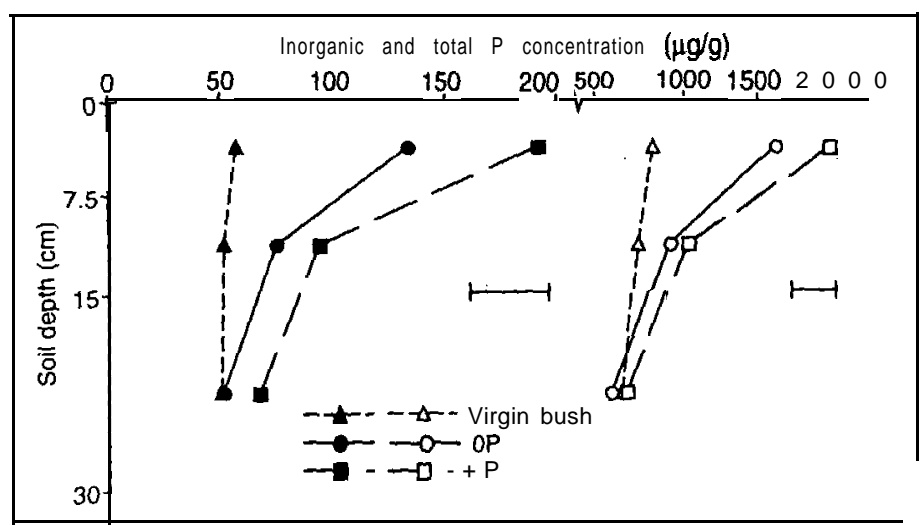


present in soil. Thus, $91 \%$ of the added P could be accounted for and most of this (about $80 \%$ ) had accumulated in soil organic $P$.

\section{Conclusions}

Withholding $\mathrm{P}$ fertiliser for 10 years reduced total pasture production by one-third and decreased legume production by two-thirds. The relative decline was evident throughout the year, indicating little difference in seasonality of production.

The loss in production was expected from the low soil Olsen $\mathrm{P}$ and inorganic $\mathrm{P}$ status. In addition, soil organic P levels were still increasing at this site and this will have represented a source of removal of plantavailable $P$.

Reapplication of $\mathrm{P}$ fertiliser, even at $23 \mathrm{~kg} \mathrm{P} / \mathrm{ha}$, led to a marked response in legume growth which was proportionally higher on steep slopes and was most evident in summer, thereby providing an improvement in feed quality at an important time of year for finishing lambs.

\section{ACKNOWLEDGEMENTS}

We are grateful to Nick Dodds and Mike Sprosen for technical assistance, Ken Perrott for discussions on soil P methodology, John Waller and Catherine Cameron for statistical analyses, and BOP Fertiliser Ltd for funding assistance.

\section{REFERENCES}

Edmeades, D.C.; Wheeler, D.M.; Rys, G.; Smith, N. 1990. Effect of pasture composition on lime and phosphorus responses on a dryland soil. Proceedings of the New Zealand Grassland Association 52: $171-175$.
Hewitt, A.E. 1992. New Zealand Soils Classification. DSIR Land Resources Scientific Report N 0. 19. 133p.

Lambert, M.G.; Clark, D.A.; Mackay, A.D. 1990. Long term effects of withholding phosphate application on North Island hill country: Ballantrae. Proceedings of the New Zealand Grassland Association 51: 25-28.

Ledgard, S.F.; Brier, G.J. 1993. Response to reapplication of phosphate fertilisers on hill pasture where fertiliser had been withheld for seven years. Proceedings of the New Zealand Grassland Association 55: 67-71.

Ledgard, SF.; Steele, K.W. 1992. Biological nitrogen fixation in mixed legume/grass pastures. Plant and soil 141: 137-153.

Ledgard, S.F.; Johnston, T.J.M.; Edmeades, D.C.; Wheeler, D.M. 199 1. Soil nutrient status of the Bay of Plenty region and the implications to pasture productivity and fertiliser requirements. Proceedings of the New Zealand Grassland Association 53: 175-179.

Mackay, A.D.; Tillman, R.W.; Parker, W.J.; Barker, D.J. 1990. Effect of superphosphate, lime, and cocksfoot on summer dry hill country pasture production. Proceedings of the New Zealand Grassland Association 51: 13 1-1 34.

Morton, J.; Roberts, A.H.C.; Edmeades, D.C. 1994 Fertiliser use on sheep and beef farms. New Zealand Fertiliser Manufacturers Research Association. 37p.

O'Connor, M.B.; Smart, C.E.; Ledgard, SF. 1990. Long term effects of withholding phosphate application in North Island hill country: Te Kuiti. Proceedings of the New Zealand Grassland Association 51: 21-24.

Perrott, K.W. 1992. Utilisation of inorganic and organic soil phosphorus in a hill country soil. Proceedings of the New Zealand Grassland Association 54: 65-69. 